\title{
ANALISIS PELAPORAN PAJAK PERTAMBAHAN NILAI (PPN) \\ DENGAN APLIKASI E-FAKTUR \\ PADA PT RAMADHAN CATURKARSA LAYORDA TEGAL
}

\author{
Ririh Sri Harjanti ${ }^{1}$, Nurul Mahmudah ${ }^{2}$, Ida Farida ${ }^{3}$, \\ email : ririh.sriharjanti77@gmail.com \\ DIII Akuntansi Politeknik Harapan Bersama \\ Jln. Mataram No.09 Tegal \\ Telp/Fax (0283)352000
}

\begin{abstract}
Abstrak
Dengan adanya pelaporan Pajak Pertambahan Nilai (PPN) dengan aplikasi E-Faktur diharapkan suatu perusahaan mudah dalam administrasi perpajakan. Penelitian ini bertujuan untuk mengetahui bagaimanakah pelaporan Pajak Pertambahan Nilai (PPN) dengan aplikasi E-Faktur pada PT Ramadhan Caturkarsa Layorda Tegal. Metode Penelitian yang digunakan pada penelitian ini adalah metode analisis Deskriptif Kualitatif dan kuantitatif yaitu analisis data dengan mendeskripsikan informasi yang diperoleh yaitu mekanisme penggunaan aplikasi e-faktur, pajak keluaran berdasarkan faktur keluaran, pajak masukan berdasarkan faktur masukan, dan pelaporan PPN dengan aplikasi e-faktur pada perusahaan terkait untuk tahun 2017. Berdasarkan hasil penelitian diperoleh gambaran bahwa PT Ramadhan Caturkarsa Layorda Tegal dalam menerapkan aplikasi e-faktur untuk menerbitkan faktur, dan pelaporan PPN sudah sesuai dengan peraturan perundang - undangan Perpajakan. Selama tahun 2017, diketahui bahwa perusahaan senantiasa tepat waktu dalam pelaporan PPN dengan aplikasi EFaktur. Sehingga dapat disimpulkan bahwa pelaporan Pajak Pertambahan Nilai (PPN) dengan aplikasi e-Faktur pada perusahaan sudah sesuai dengan peraturan perpajakan yang berlaku.
\end{abstract}

Kata kunci : Pelaporan,,Pajak Pertambahan Nilai, E-Faktur 
PENDAHULUAN

Pajak merupakan salah satu sumber penerimaan terbesar bagi Negara Indonesia. Penerimaan Negara dari pajak menjadi sumber pendapatan negara yang semakin hari semakin penting. Hal ini dikarenakan pembiayaanpembiayaan negara dipenuhi dari sektor pajak. Kepatuhan membayar pajak merupakan perwujudan dari kewajiban kenegaraan dan peran serta Wajib Pajak untuk secara langsung dan bersama-sama melaksanakan kewajiban perpajakan dalam pembangunan nasional..Menurut Idrus, dkk. (2017) ${ }^{[1]}$ menjelaskan bahwa Penerimaan Pajak yang kurang maksimal dikhawatirkan menyebabkan pemerintahan mengalami kesulitan untuk membiayai seluruh pengeluaran negara.
Menurut (Sarah dan Sandra, 2016) ${ }^{[2]}$ Sistem pemungutan Pajak Pertambahan Nilai ( PPN ) di Indonesia menganut metode pengkreditan (credit method). Pada sistem ini menerangkan bahwa Pengusaha Kena Pajak ( PKP ) yang memungut Pajak Pertambahan Nilai ( PPN ) ketika melakukan penjualan atau penyerahan, akan mengurangkan terlebih dahulu dengan Pajak Pertambahan Nilai ( PPN ) yang telah dibayar ketika membeli barang dan atau jasa. Misalnya, PT Doremi melakukan penjualan selama bulan Januari 2017 Rp 25.000.000.000 ( Rp 25 Milyar ) dan melakukan pembelian dalam periode yang sama sebesar Rp 15.000.000.000 ( Rp 15 Milyar ). Pajak Pertambahan Nilai ( PPN ) yang harus dipungut pada saat penjualan adalah $10 \% \quad \mathrm{x} \quad \mathrm{Rp}$ 25.000.000.000 = $\mathrm{Rp}$ 2.500.000.000 Milyar $=\operatorname{Rp} 2,5$ Milyar. Bagi PT Doremi, Pajak 
Pertambahan Nilai ( PPN ) yang dipungutnya tersebut disebut dengan Pajak Keluaran.

Sementara itu, jika seluruh pembeliannya kena PPN, maka PPN yang telah dibayar oleh PT Doremi adalah 10\% x Rp15 Milyar = Rp 1,5 Milyar. Bagi PT Doremi, pajak yang telah dibayarnya disebut Pajak Masukan. Selisih Pajak Keluaran dikurangi Pajak Masukan adalah Pajak Pertambahan Nilai ( PPN ) yang harus disetor ke kas negara. Dalam kasus PT Doremi, selisihnya adalah sebesar Rp 1.000.000.000 ( Rp 1 Milyar ) yang harus disetor ke kas negara. Jika Pajak Masukannya malah lebih besar daripada Pajak Keluaran, maka kelebihannya bisa diminta ke kas negara atau direstitusi.

Atas kegiatan atau transaksi penjualan dan pembelian yang dilakukan oleh Pengusaha Kena Pajak ( PKP ) maka Pengusaha Kena Pajak ( PKP ) mempunyai kewajiban dengan adanya pembayaran Pajak Pertambahan Nilai ( PPN ) dengan menggunakan Faktur Pajak. Menurut Mardiasmo (dalam Maria,dkk. 2018 ${ }^{[3]} \quad$ E-Faktur adalah bukti pungutan pajak yang dibuat oleh Pengusaha Kena Pajak (PKP) yang melakukan penyerahan Jasa Kena Pajak (JKP) dan/atau Barang Kena Pajak (BKP).

Sedangkan menurut Lintang,dkk. (2017) ${ }^{[4]}$ menyatakan bahwa E-Faktur diluncurkan oleh Direktorat Jenderal Pajak bertujuan untuk meminimalisir kecurangan yang sering terjadi dalam hal pelaporan pajak terutang serta mempermudah tata cara pelaporan Surat Pemberitahuan (SPT)

Pengguanaan E-Faktur untuk pelaporan PPN diatur dalam Peraturan Direktur Jenderal Pajak Nomor PER 16/PJ/2014 sebagaimana telah diubah dengan Peraturan Direktur Jenderal Pajak 
Nomor PER 31/PJ/2017 Tentang

Tata Cara Pembuatan dan Pelaporan Faktur Pajak Berbentuk Elektronik. Pelaksaaan aplikasi EFaktur dilakukan secara bertahap mulai 1Juli 2014, 1 Juli 2015 dan yang terakhir 1 Juli 2016. Penggunaan E-Faktur diharapkan dapat memberikan kemudahan dan ketertiban bagi Pengusaha Kena Pajak (PKP) dalam pelaporan PPN.

Perusahaan di Kabupaten Tegal umumnya bergerak dalam bidang perdagangan dan distributor dimana dalam usahanya sudah memenuhi syarat sebagai Pengusaha Kena Pajak (PKP) yang seharusnya berkewajiban untuk melaporkan Pajak Pertambahan Nilai (PPN) menggunakan $e$ Faktur sesuai dengan Peraturan PER-31/PJ/2017.

Mengingat pentingnya arti dan fungsi e-faktur dalam pelaporan PPN bagi Perusahaan, maka peneliti melakukan penelitian dengan judul "Analisis Pelaporan Pajak Pertambahan Nilai (PPN) Dengan Aplikasi EFaktur Pada PT Ramadhan Caturkarsa Layorda Tegal”.

\section{Metode Penelitian}

Penelitian ini menggunakan metode deskriptif. Menurut Maria,dkk. (2018) ${ }^{[3]} \quad$ Metode deskriptif adalah suatu analisis mengumpulkan, menyusun , mengolah, dan menganalisi data agar dapat memberikan suatu keadaan tertentu sehingga dapat ditarik kesimpulan. Sedangkan menurut Sugiyono (Lintang,dkk. 2017) $)^{[4]}$ menjelaskan bahwa penelitian deskriptif adalah penelitian yang digunakan untuk menyelidiki keadaan kondisi atau hal-hal lain yang sudah disebutkan, yang hasilnya dipaparkan dalam bentuk laporan penelitian. 
Maka dari itu penelitian deskriptif adalah penelitian yang mendiskripsikan suatu keadaan dalam bentuk data serta menganalisa data tersebut.

Jenis data yang digunakan adalah data kualitatif dan kuantitatif dimana menjelaskan tentang pelaporan Pajak Pertambahan Nilai (PPN) dengan aplikasi E-Faktur pada perusahaan terkait untuk periode tahun 2017.

Sumber Data yang digunakan adalah sumber data sekunder, berupa data tentang pelaporan PPN dengan aplikasi e-faktur.

\section{Hasil dan Pembahasan}

3.1 Perbedaan Pelaporan PPN sebelum dan sesudah menggunakan aplikasi e-faktur Pada PT RCL Tegal

Perusahaan mulai menggunakan aplikasi e- faktur pada bulan Juli 2015. Berikut perbedaan pelaporan PPN sebelum menggunakan aplikasi dan sesudah menggunakan aplikasi efaktur :

Tabel 3.1

Perbedaan Pelaporan PPN sebelum dan sesudah menggunakan aplikasi efaktur Pada PT RCL Tegal

\begin{tabular}{|c|c|c|}
\hline $\mathbf{N}$ & $\begin{array}{l}\text { Keteranga } \\
\text { n }\end{array}$ & Sebelum \\
\hline 1 & $\begin{array}{l}\text { Penerbitan } \\
\text { Nomor Seri } \\
\text { Faktur } \\
\text { Pajak } \\
\text { (NSFP) }\end{array}$ & $\begin{array}{l}\text { NSFP dari } \\
\text { Perusahaan (PKP) }\end{array}$ \\
\hline 2 & $\begin{array}{l}\text { Tanda } \\
\text { Tangan } \\
\text { yang } \\
\text { ditunjuk }\end{array}$ & $\begin{array}{l}\text { Tanda Tangan basah } \\
\text { diatas faktur pajak } \\
\text { kertas }\end{array}$ \\
\hline 3 & $\begin{array}{l}\text { Pembetulan } \\
\text { Faktur } \\
\text { Pajak }\end{array}$ & $\begin{array}{l}\text { Faktur yang direvisi } \\
\text { bisa langsung dirubah } \\
\text { tanpa membuat } \\
\text { Faktur Pengganti }\end{array}$ \\
\hline 4 & $\begin{array}{l}\text { Prosedur } \\
\text { Pembayara } \\
\text { n PPN }\end{array}$ & $\begin{array}{l}\text { Membuat SSP } \\
\text { Manual }\end{array}$ \\
\hline
\end{tabular}




\begin{tabular}{|c|c|c|}
\hline 5 & $\begin{array}{l}\text { Prosedur } \\
\text { Pelaporan } \\
\text { PPN }\end{array}$ & $\begin{array}{l}\text { Tidak terhubung } \\
\text { dengan internet dalam } \\
\text { pelaporan PPN }\end{array}$ \\
\hline $\mathbf{0}$ & $\begin{array}{l}\text { Keteranga } \\
\text { n }\end{array}$ & Sesudah \\
\hline 1 & $\begin{array}{l}\text { Penerbitan } \\
\text { Nomor Seri } \\
\text { Faktur } \\
\text { Pajak } \\
\text { (NSFP) }\end{array}$ & $\begin{array}{l}\text { NSFP dari } \\
\text { persetujuan } \\
\text { Direktorat Jenderal } \\
\text { Pajak (DJP) }\end{array}$ \\
\hline 2 & $\begin{array}{l}\text { Tanda } \\
\text { Tangan } \\
\text { yang } \\
\text { ditunjuk }\end{array}$ & $\begin{array}{l}\text { Tanda tangan } \\
\text { elektronik berbentuk } \\
\text { QR code }\end{array}$ \\
\hline 3 & $\begin{array}{l}\text { Prosedur } \\
\text { Pembayara } \\
\text { n PPN }\end{array}$ & $\begin{array}{l}\text { Menggunakan } \\
\text { ebilling sebagai } \\
\text { pengganti SSP } \\
\text { Manual. }\end{array}$ \\
\hline 4 & $\begin{array}{l}\text { Prosedur } \\
\text { Pelaporan } \\
\text { PPN }\end{array}$ & $\begin{array}{l}\text { Terhubung dengan } \\
\text { internet dalam } \\
\text { pelaporan PPN }\end{array}$ \\
\hline
\end{tabular}

Secara umum dapat dijelaskan bahwa mekanisme dan prosedur pelaporan PPN dengan aplikasi efaktur sudah sesuai dengan peraturan Direktur Jenderal Pajak Nomor PER 31 /PJ/2017.
3.2 Pelaporan PPN dengan Aplikasi E-Faktur Pada PT Ramadhan Caturkarsa Layorda Tegal :

Dengan berlakunya aplikasi e-faktur sebagai salah satu sofware resmi untuk membuat faktur pajak serta melaporkan SPT Masa PPN maka selaku Wajib Pajak harus mengikuti aturan tersebut. Berikut langkah - langkah Untuk membuat laporan SPT Masa PPN dengan aplikasi e-faktur :

1). Buka Aplikasi Efaktur dengan mengklik EtaxInvoice

2). Pilih localDatabase dan Klik Connect

3). Masukan Nama User dan Password sesuai dengan setting awal pada waktu install E-faktur 4). Setelah berhasil masuk, Pilih SPT dan Klik menu Posting

5). Pilih Masa Pajak dan Tahun Pajak sesuai dengan Masa yang akan dilaporkan, kemudian isi pembetulan dengan kode $\mathbf{0}$, 
6). Selanjutnya klik Cek Jumlah Dok. PKPM dan Klik Posting sehingga muncul pesan Data SPT Berhasil Dibentuk.

\section{Kesimpulan}

Berdasarkan hasil dan pembahasan penelitian pada perusahaan terkait dapat peneliti mengambil kesimpulan :

1) Mekanisme dan prosedur penggunaan aplikasi E-Faktur pada pelaporan PPN pada perusahaan terkait telah sesuai dengan Peraturan Direktur Jenderal Pajak Nomor PER 31/PJ/2017 Tentang Tentang Perubahan Kedua Atas Peraturan Direktur Jenderal Pajak Nomor PER-16/PJ/2014 Tentang Tata Cara Pembuatan Dan Pelaporan Faktur Pajak Berbentuk Elektronik

2) Perusahaan selama tahun 2017 telah melaporkan SPT Masa
PPN dengan aplikasi e-Faktur dengan tertib.

3) Ketertiban dalam pelaporan PPN disebabkan karena pengetahuan perusahaan terhadap peraturan perpajakan terutama pelaksanaan aplikasi eFaktur sudah cukup memadai.

Berdasarkan hasil penelitian, kesimpulan dan implikasinya, maka penulis mengajukan saransaran sebagai berikut :

1) Pelaporan Pajak Pertambahan Nilai (PPN) dengan aplikasi efaktur sudah sesuai dengan peraturan perpajakan yang berlaku, hal ini merupakan keunggulan perusahaan yang perlu dipertahankan.

2) Perusahaan tetap mempertahankan jaringan yang cukup bagus guna mempelancar proses pelaporan 
Pajak Pertambahan Nilai (PPN) pada aplikasi $e$-Faktur.

\section{Daftar Pustaka}

[1] Idrus, dkk. (2017). Analisis perhitungan Dan Pelaporan pajak Pertambahan NIlai (Studi Kasus Pada PT Anggada Karsa Utama) Periode Tahun 2014 s/d 2015)

[2] Sarah dan Sandra. (2016). Analisis Pemberlakuan EFaktur PPN Pada PT ABC

[3] Maria, dkk. (2018). Analisis Penerapan E-Faktur Dalam Prosedur Dan Pembuatan Faktur Pajak Dan Pelaporan SPT Masa PPN Pada CV. Wastu Citra Pratama

[4] Lintang, dkk. (2017). Analisis Penerapan E-Faktur Pajak Dalam Upaya Meningkatkan Kepatuhan
Pengusaha Kena Pajak

Untuk Pelaoran SPT Masa PPN Pada KPP Pratama

Manado 